\title{
Missile spin-off creates activity
}

\section{MX research an ill-wind brings good}

\section{Washington}

Research centres around the United States will benefit from President Reagan's determination to press ahead with the MX missile. As long as the fate of the 70-foot long missile and its method of deployment hangs in the balance, lots of money must be spent to keep the teams together and to work on the problems under debate.

At the time of going to press, Congress had effectively deleted $\$ 988$ million for production of the first five MX missiles, and seemed likely to attach conditions to parts of the $\$ 2,500$ million MX research and development budget. But most of this amount seemed likely to go forward, as would other parts of the defence budget that related to research, such as funds for Ballistic Missile Defense (BMD) research.

The Ballistic Missile Office of the Air Force pays out this money, most of it to prime contractors, to engineer and test the components of the missile. As with other major weapons systems, the MX's contractors are scattered around the country (often in the districts of important members of Congress).

The Ballistic Missile Office also buys research from other parts of the Air Force to work on the basic problem of what would happen in a Soviet attack and how many MXs would survive. The computers that explore these scenarios belong to the Strategic Air Command, but other offices, such as the Air Force's Office of Studies and Analysis (which judges the "military utility" of total weapons systems), do the analysis.

The "super-hardening" of silos is studied by the Defense Nuclear Agency (DNA), a separate Department of Defense agency whose job is to assess the effects of nuclear explosions. In 1982 DNA reported on a series of tests it had made of blasts over super-hardened silos, which showed they could survive. But the tests were made by combining ordinary explosives to simulate the blast of a 25 megaton nuclear explosion, which makes the conclusion suspect, according to Kosta Tsipis, director of the Massachusetts Institute of Technology programme in Science and Technology for International Security.
Two of the national laboratories, Lawrence Livermore and Los Alamos, are expert in the disturbed environment into which nuclear warheads must fly - and so study problems related to the MX basing mode too.

The Army's BMD programme is also gaining research funds as a result of the need to design a system that could defend the "dense pack" missile field. The BMD programme contracts with private universities such as Stanford, CarnegieMellon and the Georgia Institute of Technology.

Outside experts who oppose the plan, such as IBM's Richard Garwin, are few, but powerful. If the dense pack plan is rejected, as other, previous basing modes have been, it may be because the research that underpins it is so scattered.

Deborah Shapley

\section{US Congress cops out}

\section{Washington}

The lame-duck Congress went out with a whimper, not a bang, this week, having failed to act on any of the many scienceand technology-related initiatives brought before it this year.

The last hectic hours of the session were taken up with marathon all-night and weekend efforts to agree on a stop-gap bill to keep the government running until September 1983, the end of the fiscal year. The bill that finally emerged from the full Congress, after repeated delaying tactics by Senate opponents of one or another of its provisions, does the following:

- Clinch River breeder reactor. $\$ 181$

\section{Dense pack logistics}

On 22 November, the President submitted a "dense pack" basing proposal for the new MX missile to Congress to persuade it to release $\$ \mathbf{7 1 5}$ million for research on basing modes in the budget for fiscal year 1983 then being finalized. The plan would put 200 of the highly accurate missiles into a $\mathbf{2 0}$-square mile area, at an Air Force base in Wyoming, in silos that would be "super-hardened" so as to withstand a massive pressure of 100,000 pounds per square inch. The MX missiles would be packed 1,800 feet apart, so that incoming Soviet warheads would have to burst near each other and destroy one another through a phenomenon known as fratricide. The Air Force, which runs the MX programme, argued that at least $100 \mathrm{MXs}$ in their silos could survive an all-out Soviet attack; because they would be left to retaliate, the Soviet Union would not attack in the first place.

But many in Congress, including conservatives usually supportive of President Reagan's defence programme, attacked the plan. Bolstered by advice from outside experts, they doubted whether the Air Force could so suddenly have discovered "superhardening", or that fratricide would really occur, or that dense pack would survive exotic methods of attack, such as having the warheads dig up the ground. Moreover, the Air Force admitted that the survivability of dense pack would ultimately depend on building a ballistic missile defence system, something the United States and the Soviet Union virtually renounced by treaty in 1972.

The House voted by 245 to 176 to delete production funds for the missile: the Senate approved the production funds but with a condition that they not be spent until the dense pack plan and the alternatives had been restudied and submitted to the next Congress. The net effect was correction Congress' action was the first serious rebuff to the President's ambitious defence programme. Deborah Shapley million has been provided to keep this controversial project alive. But opponents, who last week thought they had finally delivered Clinch River a death blow when the House of Representatives voted its funds, did win a freeze on construction and a study of the project's usefulness.

- Regulation of doctors. The HouseSenate compromise knocks out a rider by the American Medical Association that would have barred the federal government from investigating and regulating the trade practices of doctors and other professionals. The amendment had passed the House, but not the Senate.

The science- and technology-related bills left to die include:

- Nuclear waste disposal. The United States still has no comprehensive plan for the construction of a permanent repository from commercial nuclear waste or for the interim storage of spent fuel. A legislative initiative in the last Congress, two years ago, was also killed off at the last minute. - Immigration reform. This legislation would have imposed new restrictions on the employment of foreign students after their graduation from US universities. The bill was defeated in the House largely due to opposition from Hispanic groups concerned about its other provisions.

- Animal rights. This bill would have required laboratories receiving federal research funds to upgrade their animal facilities and institutional controls on the use of animals in research. The National Institutes of Health may however adopt some of the bill's provisions anyway.

- Clean Air Act. A two-year effort to reauthorize the basic air pollution control law and to add new provisions for the abatement of acid rain failed to get out of committee. The present statute remains in effect. 